\title{
Representation of Mutual Cooperation Values as Local Wisdom in the Text of Pasambahan Manjapuik Marapulai in Solok City
}

\author{
Zulfian Elfiando \\ Candidate Doctorate in Linguistics \\ Faculty of Humanities Udayana University Denpasar Bali Indonesia \\ Prof. Dr. Ni Luh Sutjiati Beratha, M. A. \\ Professor in Linguistics \\ Faculty of Humanities Udayana University Denpasar Bali Indonesia \\ Prof. Dr. I Ketut Darma Laksana, M. Hum \\ Professor in Linguistics \\ Faculty of Humanities Udayana University Denpasar Bali Indonesia \\ Prof. Dr. Oktavianus, M. Hum \\ Professor in Linguistics \\ Faculty of Humanities Andalas University \\ Padang West Sumatera Indonesia
}

\begin{abstract}
One of the values of local wisdom that is still inherited by the Minangkabau people and which is still maintained by indigenous peoples in the city of Solok is pasambahan. Pasambahan is a sacred ceremony, because every ceremony is carried out in a customary manner, the pasambahan must be present. Once the importance of pasambahan in the marriage process, if it is not carried out pasambahan ceremony can have adverse consequences on ongoing activities. Pasambahan manjapuik marapulai 'pasambahan picking up the bridegroom' is one of the oral traditions of Minangkabau people in Solok city. In Minangkabau tradition, marapulai 'bridegroom' is picked up customarily by the bride's family to be married and juxtaposed in the bride's family house.The marriage process of manjapuik marapulai in Minangkabau customs is carried out in mutual cooperation. In text of pasambahan manjapuik marapulai, it is reflected the values of mutual cooperation which is the local wisdom of Minangkabau people in general, the people of Solokcity in particular. The purpose of this research is to represent the values of mutual cooperation in the text of pasambahan manjapuik marapulai as the local wisdom of the Minangkabau people in general, the people of Solok city in particular. This study uses qualitative methods with purposive sampling technique. In addition, a focus group discussion (FGD) was also conducted on various fields of speech. The data of this study are oral text of pasambahan manjapuik marapulai in Solok city which have been transcribed. In addition, this study also uses written sources to support the primary data. Data analysis is begun with data reduction, data presentation, and verification. Based on conducted research, it is found the values of mutual cooperation as local wisdom in the process of traditional marriage ceremony in Solok city. The values of mutual cooperation are togetherness, unity, mutual respect and tolerance.
\end{abstract}

Keywords: mutual cooperation, local wisdom, pasambahan manjapuik marapulai in Solok city

\section{Introduction}

Local wisdom is the wisdom or original knowledge of a community that comes from the noble values of cultural traditions to regulate the order of people's lives (Sibarani, 2014).These values can be seen in the traditions and habits of a society, such as mutual cooperation, willing to sacrifice, mutual respect and tolerance. Cultural values and norms that can be applied in managing social life is a form of local wisdom that must be studied in depth to build character and identity of the community. Indigenous people traditionally continue to adhere local values. One of them is mutual cooperation which is believed to be the truth that holds the life of its members who are inherited from generation to generation. These values are interrelated in a system (Nurlatifah, 2017). One of the values of local wisdom possessed by the Indonesian people in general, the Minangkabau community in particular is mutual cooperation. This is in line with Collette's opinion (1987: 3) which mentions that mutual cooperation has entrenched in the lives of Indonesian people and is the most important original institution in community development. 
The same thing was expressed by Oktara, M. Hidayat Dwi (2014) that mutual cooperation is one manifestation of the values of local wisdom. Pasya (2015) revealed that mutual cooperation can occur in the form of help when performing a wedding, or circumcision. A few days before the party will be held, acquaintances, neighbors and relatives come to provide assistance in the form of energy, mind, and in the material. Firman (2015) said that the Minangkabau community still adhered to the feeling of solidarity carried out by cooperating together. The mutual cooperation spirit is also reflected in the Minangkabau community. This can be found in one of the oral traditions at the ceremony of marriage in Minangkabau tradition. One of these traditions is pasambahan manjapuik marapulai 'pasambahan picking up the bridegroom' in Solok city, West Sumatra Province.

Minangkabau people mention their area as "nature" or "realm" alam takambang manjadi guru 'the developing world being the teacher' which is the basis of the thinking of the Minangkabau community (Navis, 1984). This expression is a manifestation of Minangkabau people in carrying out their lives and habits, which became the customs and guidelines of the Minangkabau people. The Minangkabau custom is a concept of life designed and prepared by their ancestors to achieve the welfare of the entire Minangkabau community. Local wisdom as mentioned above can be realized through the thoughts, attitudes and actions of the people.

In communal communities especially the Minangkabau people, there are diverse cultures. In its implementation, the diversity is based on the customs in each region in Minangkabau such as the traditional proverb mutually adat selingkar nagari (in an area agreed upon by the community concerned). One of the customs intended is customary in the marriage process. The marriage process in Minangkabau customs is carried out in mutual cooperation. This is implicit in the expression nikah jo parampuan, kawin korong jo kampuang 'marriage with women, marrying villages with villages'(Navis, 1984).The Minangkabau community considers that marrying is not only a matter of relations between the two brides, but the relationship between the two families, the two villages, even between the two regions if the area is different. This indicates that in the text of pasambahan ceremony reflected the values and customary norms that applied in the Minangkabau community (Djamaris, 2001: 64).

If it is examined linguistically, text of pasambahan manjapuik marapulai (here in after abbreviated as TPMM) takes the form of metaphorical, such as proverbs, figures of speech, parables, and proverbs that require semantic and pragmatic interpretation. Every speech act contained in the TPMM verses essentially reflects the socio-cultural values in Minangkabau. In addition to be being one of the ethnic groups that displays a certain culture, the Minangkabau community also inherits the teachings of traditional values that should be preserved. The values of customs in Minangkabau people are still used and maintained. The forms of expression contained in TPMM consist of linguistic elements in the form of phrases, clauses or sentences believed containing the values of mutual cooperation, which is one of the local wisdoms of the Minangkabau community.

In the communal of Minangkabau community, all tasks are a shared responsibility, the nature of mutual cooperation is a necessity, mutual support and help are obligations. The Minangkabau culture teaches that bareksamodipikua,ringansamodijinjiang'the same weight and light are carried out together'. The proverb contains the value of mutual cooperation. The participation of the Minangkabau people in social life can be seen from their intimacy with their neighbors. If there are neighbors who are in distress they are not reluctant to help, attend weddings, mourn when there are death events, and so forth. Pasambahan in Minangkabau diminished in use. It can be seen that the discourse on the variety of pasambahan customs which are usually used in traditional ceremonies, has been neglected by Minangkabau people now, especially in urban areas, such as in Solok city. This is based on the facts that many young people do not understand the phrases in the text of pasambahan that are proverbial, thimble, and figurative. This is of course can lead to silencing of moral values accompanied by a crisis of the identity and personality of Minangkabau people. This problem is feared to threaten the integration of national unity and the resilience of local and national culture. This crisis has made all components of society aware of the importance of cultural resilience in people's lives.

A number of researches on pasambahan has been done. Among these are research conducted by (i) Bakar, et al. (1976), (ii) Udin, et al. (1984), (iii) Elfiando (2000), and (iv) Rosa (2013). The following are presented at a glance the studies. First is a study conducted by Bakar, et al. (1976). The study conducted by Bakar, et al (1976) does not refer to a particular theory. The study only briefly describes the essence and the role of speech of pasambahan in Minangkabau society. Based on the results of those studies, Bakar, et al. (1976) claimed that pasambahan is still rooted in Minangkabau community and is used in all circles. They have also seen the existence of pasambahan in Minangkabau community even though they have not studied the meaning and values contained in pasambahan.

Although it does not discuss the lingual aspect, Bakar's research certainly contributes to the researchers, especially the researchers who understand the pasambahan concepts that have relevance to this additional passive text research. 
Second is the research conducted by Udin et al. (1984). Udin, et al. (1984) contributes to this TPMM research. The contributions to this research include clarifying basic concepts, roles, and additional functions. In addition, pasambahan reflects the culture and value of people's lives symbolic and metaphoric. According to Udin et al., the tradition of pasambahan is still guaranteed to its sustainability as reflected in the Minangkabau traditional proverb which is timeless, not weathered by rain as traditional proverb adat basandi syarak 'custom jurisdiction over religious, religion jointed with the book of Allah (alqur'an) which finally merged with Islamic teachings.

Third is Elfiando (2000). Elfiando (2000) examines one type of pasambahan in marriage processions in Solok municipality (now, administratively named Solok city), namely pasambahan mananti marapulai, 'pasambahan of waiting for the bridegroom'. In his research, Elfiando discusses the components, types, and functions of speech acts at the pasambahan mananti speech in Solok city. By using qualitative methods with recording techniques and recorded techniques proposed by Sudaryanto (1993), in the process of collecting data the results shows that the illocution meaning of speech acts at pasambahan mananti marapulai 'pasambahan of waiting bridegroom' reflects deliberation and consensus, the ideology of Minangkabau society, togetherness and kinship, mutual respect, equality of status, upholding ethical values and politeness and social control. In addition, the results of his research shows that in this customary discourse, it tends to be an indirect speech act. Meanwhile, the speech act function in pasambahan speech is a combination of expressive, directive, representative, commissive, and declarative functions.

Fourth, research conducted by Rosa, (2013). Rosa (2013) examines the Pasambahan of Batagak Gala' pasambahan of awarding Minangkabau traditional title in the Roland Barthes semiological perspective. In her research, Rosa reveals the inheritance of customary titles according to the matrilineal kinship of niniak mamak to his nephew who would or become a marapulai. The tradition of this awarding title is still carried out by Minangkabau people, those who live in luhak environment and those who live in overseas environment, although there are some cultural differences between the two environments.

Based on the literature review above, it can be said that the study of pasambahan has been carried out by several previous researchers. The difference in this study with previous studies in general can be seen from several aspects. The aspects that distinguish it from previous research are: first, the theory used. Previous research, such as (i) Bakar, et al. (1976), (ii) Udin, et al. (1984), (iii) Elfiando (2000), and (iv) Rosa (2013) use a different theory from this study. Bakar, et al. not mentioning the theory used, Udin uses the Wellek Literature theory, and Elfiando (2000) uses speech act theory. The difference between Elfiando (2000) research and this TPMM research lies in the objects studied and the theories used. Previous research only examined pasambahan mananti marapulai, 'pasambahan of waiting for the bridegroom' Solok municipality using the theory of speech act, while the TPMM uses the theory of local wisdom that examined the values of mutual cooperation as local wisdom.

\section{Theoretical Framework}

To express the local wisdom of Minangkabau culture related to mutual cooperation found in TPMM, it is guided by the Big Indonesian Language Dictionary (1988), the opinion of Kartodirjo (1994) and Pranadji (2009) about mutual cooperation, and the opinion of Sibarani (2014) on local wisdom. The following is an explanation of each of these opinions.

\subsection{Mutual Cooperation}

In the Big Indonesian Dictionary (1988) it is said that mutual cooperation is defined as working together, help to each other. In mutual cooperation activities there is an agreement or agreement on the things that will be done in mutual cooperation. Kartodirdjo (1994: 91) says that mutual cooperation is a manifestation of solidarity that is evident as a characteristic in rural communities. The implementation of the pasambahan manjapuik marapulai tradition in Solok city carried out together is a manifestation of apparent solidarity as a characteristic of rural communities. The same thing was expressed by Pranadji (2009: 71) that mutual cooperation is a wealth of customs and the core of the nation's socio-cultural moral values, which contain cultural values (customs) and socio-culture from various tribes and communities spread throughout corners of the archipelago.

\subsection{Local Wisdom}

The phrase of local wisdom consists of two words, namely local and wisdom. The word wisdom means wisdom, while the local word means local. In general, local wisdom means local ideas that are wise, full of wisdom, good value, virtuous possessed, guided and carried out by members of their community. Local wisdom obtained from a downturn originating from cultural values is used to organize the life of a community (Sibarani, 2014). To find out a local wisdom in a region, it is necessary to understand the cultural values that exist within the region. Culture of mutual cooperation, mutual respect is an example of local wisdom (Herlina, 2018). 


\section{Research Methods}

This study is an attempt to carry out a description and comprehensive understanding of the values of mutual cooperation as local wisdom in the text of pasambahan manjapuik marapulai in Solok City. This study is conducted qualitatively by adhering to an inductive approach (Moleong, 2005).

\subsection{Data Collection Method}

In collecting data research of TPMM, observations were carried out with direct participatory observation methods using senses to observe descriptions of activities, behavior, actions, social interactions, and social processes of Minangkabau community. This is intended, so that all information can be captured by the researcher so that there is an understanding and comprehensive appreciation of the TPMM. In making these observations a recording device, it is used to record the intended activity. The skillful free listening method is used primarily to get an idea of the values of mutual cooperation as local wisdom contained in the text of pasambahan manjapuik marapulai in Solok city. In addition, interview technique is used. This interview technique is needed to see the values of mutual cooperation as local wisdom. In addition, a focus group discussion (FGD) is also conducted on various domains of speech (Djajasudarma, 1993: 62; Sudaryanto: 1993: 139).

In addition, focus-group discussions is held. This method is formerly called focus-group interviews, because it is a part of the interviews conducted by researchers, but by means of discussion. This is to get information on the growth of TPMM from time to time and planning the revitalization and preservation of TPMM into the future. To test the validity of the data in this study, it is used the validity test, namely the accuracy between the data that occurred in the object of research with data that can be reported. To test the validity of this research, it is used triangulation. In addition, a reliability test is also carried out, namely a reality that is plural or multiple and dynamic, so that it is not consistent in the social paradigm.

\subsection{Participants in Pasambahan}

Participants in the pasambahan manjapuik marapulai ceremony consisted of two parties, namely bride's and bridegroom's party represented by the traditional chief / datuk, niniak mamak, and pious scholars (commonly referred to just like furnace. Besides that, it is also accompanied by Bundo Kanduang (the name of the greatness of women in Minangkabau).

\subsection{Types and Data Sources}

There are three types of data used in this study, namely primary data, secondary data, and researcher's intuition. The primary data in this study are oral data, in the form of structured and systematic speeches or dialogues carried out by host and guest groups at the addition event on marriage festivities in the Solok city, west Sumatera province which were obtained by using skilled recording techniques and listening techniques. (Sudaryanto, 1993: 139). Secondary data are in the form of written data obtained from various sources, such as oral data that has been transcribed in the form of books, and other library media. In addition, researcher also used intuition, in this case the native speakers of Minangkabau language.

\subsection{Method of Presentation of Analysis Results}

The results of this research data analysis are presented in a descriptive-narrative manner. The presentation of the results of data analysis uses a string of words referred to by Sudaryanto with informal methods (Sudaryanto, 1993: 145). The use of these methods is based on efficiency, systematization, and coherence in the results of the analysis.

\section{The Result of Data Analysis}

As stated earlier that mutual cooperation, one of the characteristics of Minangkabau culture contains various values that are able to provide positive value for the Minangkabau people. This study examines the values of mutual cooperation contained in the TPMM, namely (1) togetherness; (2) saiyo sakato 'mutual consensus'; (3) unity and togetherness; and (4) willing to sacrifice. The following is a discussion of each of these values.

\subsection{Togetherness}

In mutual cooperation activities, it is reflected togetherness that grows in the community. With mutual cooperation, the community wants to work together to help others or to build facilities that can be used together. This is because participants in mutual cooperation must work together. In doing work together, each participant works together to understand the strengths and the weaknesses of other participants. This concept is important because the work of mutual cooperation requires an understanding of the strengths or weaknesses of the participants. In addition, participants must uphold the values of togetherness that prioritize the common interests of personal interests. This is reflected in the following TPMM. 


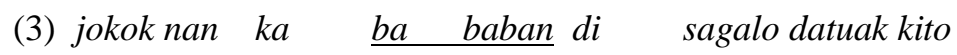
jika yang MOD. PREF. beban PREF. segala datuk 3JMK 'If there is responsibility for all of our datuk'

(4) baiak sagalo guru kito pun sakali baik semua guru 1JMK.PART. sekali 'as well as all our teachers'

The expressions (3) and (4) are fragments of TPMM delivered by the bridegroom's family. The word bababan 'has a burden' on data (3) in principle has two basic phenomena, namely the burden of life that is being and will be borne. This can be seen in the bababan 'bear the burden' in the topic, which is said to be like that if there is a burden on all of our datuaks (3).The 'burden' chapter that is being borne in this context is the marriage feast that is being carried out.The task or chapter 'burden' intended in the TPMM is essentially the responsibility of all parties or joint responsibilities. This is reflected in the use of pronoun kito 'our'. On the other hand, the expression indicates togetherness. This can be seen in the expressions of all our datuaks and our teachers( 3 and 4$)$ that the burden / task that is going to be and is running is mutual responsibility. The word 'our' at our datuak and our teacher has an inclusive meaning, which involves the partner's speech. In addition using the pronouns found in expressions (3) and (4) above, speakers also use the metaphor of sight and hearing that contains the values of mutual cooperation. This is reflected in the following expression:

(5) alah diateh rupo nan sapancaliakan sudah PREF. rupa yang sepenglihatan 'have already been seen ' (lit. equally understood)

(6) bunyi lah sapandangaran hanyo datuak bunyi MOD. sependengaran FAT. datuk 'have already been heard '(lit. equally understood)

The expressions (5) and (6) contain the value of mutual cooperation. Linguistically, the expression (5) takes the form of a metaphor that relates to the sense of sight of something, namely rupo 'form'. What becomes the figure of speech of phrase (5) is the 'equally seen / equally understood'. Something that is related to the sense of hearing is sound, like sound has been heard, datuak. Literally, expressions (5) and (6) contain meanings as they are. However, the two expressions contain the meaning of understanding the intention conveyed by the previous partner. The statement indicates that this activity is an activity carried out in mutual cooperation, in this case between the family of bride and bridegroom. Life between members in the people helping each other and supporting each other becomes an obligation. All assignments are shared responsibilities, as in the following adage.

(7) baka aua jo tabiang, sanda manyanda kaduonyo bak aur KONJ. tebing, sandar menyandar keduanya

'like thin bamboo and mountain side' (lit. each other helps each other) Hakimy, 1988; Amir, 1997).

Data (7) consists of two phrases, (i) bak aua jo tabiang like thin bamboo and mountain side' and (ii) sanda manyanda kaduonyo 'leaning on each other'. These expressions contain values that help each other and support each other. The phrase (i) is in the form of a metaphor like thin bamboo which is followed by a phrase in the form of reduplication sanda manyanda kaduonyo'leaning on each other'. Aua 'thin bamboo' is a type of bamboo plant. Aua 'thin bamboo' is often found on cliffs.Usually, the 'cliff' that are overgrown with aua 'thin bamboo' have strength, so that the land overgrown with aua is rarely landslide. Data (7) describes natural phenomena between aua 'thin bamboo' with tabiang 'cliff' which help to each other. Linguistically, this is marked by the form of reduplication on sanda manyanda kaduonyo 'leaning on each other' which have meaning help to each other. Vice versa, tabiang 'cliff' for aua 'thin bamboo' is the place to grow. It is dressed up that in communal life one must help one another, support one another, and save one another's lives and their lives from destruction. Life between members in a community that is mutually helpful is also reflected in the following adage.

(8) nan lamah makanan tueh, nan condong makanan tungkek yang lemah makan-SUFF. topang, yang condong makan-SUF. tongkat 'yang lemah ditopang, yang condong diberi tongkat' (lit. salingmembantu) 'the weak are sustained, which are inclined to stick '(lit. help each other)'

Data (8) contains values that help to each other. The figure in data (8) is lamah 'weak', tueh 'support', inclined to 'lean', and tungket 'stick'. Naturally, something weak when sustained will be strong. Likewise the case with something that is leaning when supported will become stronger. 
The proverb reflects the values of togetherness in mutual cooperation. The sense of togetherness does not only appear from above, but often emerges from below (Nasroen, 1971: 189--190) which reflects the attitude of shared responsibility as reflected in the following proverb.

kok indak titiak dari ateh, basuitkan dari bawah

kalau NEG.titik PREP. atas, pancurkan PREP. bawah

'if there is no policy from above, propose from below'

(10) iyo pulo lah bawakia sagalo datuak kito

FAT. MOD. PREF. wakil semua datuk IJMK

'it is true that it has been represented by all our datuak'

TPMM (9 and 10) contain shared responsibility values. The value of shared responsibility in this case is the 'boss' and the bottom party 'subordinate' in carrying out a policy in community life. In addition to the linguistic features above, the value of togetherness can also be seen in the dominant use of the plural first pronoun of 'us'. The use of pronoun kito 'our' in the phrase iyo pulo lah bawakia sagalo datuak kito' is true that it has been represented by all our datuak' for example, has symbolic meaning that there is no difference in the responsibilities of each group. The word kito 'our' in this context is essentially a solidarity pronoun or has a feature called Braun (1988) with the term semantic solidarity 'solidarity meaning' which refers more to features (+ similarity and + togetherness).

(11) duduak surang basampik-sampik duduak basamo balapang-lapang duduk sendiri PREP. sempit-sempit duduk bersama PREF.lapang-lapang 'duduk sendiri bersempit-sempit 'duduk bersama berlapang-lapang' (lit. salingmembantu) 'sit alone feel narrowly' sit together feel widely' (lit. help each other)

The proverb (11) contains the value of togetherness. Linguistically, the phrase consists of two clauses, namely (i) duduak surang basampik-sampik 'sitting alone feel narrowly, and (ii) duduak basamo balapang-lapang 'sitting together feel widely'. The two clauses in sentence (11) are formed with paradoxical constructs. That is said because the construction contains meaning that is contrary to nature, but it contains the truth. So, there are conflicting meanings such as the construction. Such a paradoxical construction is called as the ungkapan sonsang 'paradoxal expression' (Navis, 1984). Logically, 'sitting alone' has a room that is more spacious compared to duduak basamo 'sitting together'. However, philosophically, the expression implies that a job will feel lighter if the work is done together when compared to be being done alone. In this context, the word refers to the work carried out in a customary manner, namely manjapuik marapulai 'picking up the bridegroom'.

\subsection{Mutual Consensus 'Saiyo Sakato'}

If it is examined, the form of the expression is a compound word that consist of two words, they are saiyo and sakato. Saiyo consists of two morphemes, namely morpheme sa which means 'one', whereas iyo literally means 'yes' which means 'agree'. Sakato means 'alike'. In Minangkabau traditional, to reach consensus deliberations are held to reach consensus, not deliberation to continue the fight known as proverb saiyo sakato. In a communal society, agreeing on planning in large works, it requires a mutual agreement. The agreement is generally realized in deliberations to reach consensus, so that the implementation of a large event is expected to run smoothly. A problem or a work carried out jointly there will always be differences of opinion or standpoint between one and the others. With the principle of saiyo sakato, differences of opinion can be resolved properly. In Minangkabau indigenous people, before deciding to do a job in a traditional ceremony, it is carried out jointly, discussed with their people or with other parties. This is reflected as follows.

(12) elok kato dek baiyo, rancak rundiangan dek mupakaiak elok kata PREP. PREF.iya, bagus runding-SUFF PREP. mupakat 'nice words because of deliberation, both negotiating on consensus'
iyo alah ambo paiyokan kapado sagalo datuak kito
benar MOD. 1TGL runding-SUFF PREP. semua datuk 3JMK
'I have really negotiated with all of our datuak'

The phrase (12) elok kato dek baiyo rancak rundiangan dek mupakaiak 'nice words because of deliberation, both negotiating because of consensus'; and (13) iyo ambo paiyokan kapado datuak kito' it is really that I have already negotiated with all of our datuak 'containing the value of saiyo sakato. 
The paradigm is reinforced again by the emergence of the ambiguous pronouncement of ambo 'me' and kito 'us' in the expression iyo 'yes', ambo'I' kapado sagalo datuak kito 'to all of our datuaks' (13) which is essentially the result of deliberation and consensus among certain groups (host group or guest group) represented by someone.

The pronoun ambo 'I' and kito 'our' as in the TPMM greeting are used in parallel. In addition, the third pronoun kito 'our' beside to express personal relationships that are familiar (solidarity) or close social relations between speakers and inclusiveness contains the value of togetherness in carrying out a task and responsibility together.

\section{2. Unity and unification}

Unity and unification has the meaning of being whole or not fragmented. The word unity can be interpreted as an association of various components formed into one. While unification is the result of its relationship with wholeness. Amir (1999) says that Minangkabau custom craved unity. Minangkabau people believe that without unity and unification, it makes them distantly from the community goals they want to achieve. This is reflected in the following TPMM.

$$
\begin{aligned}
& \text { pihak dek kami nan datang lah salapeh niniak jo mamak } \\
& \text { pihak PREP. 3JMK yang datang MOD. seizin ninik dan mamak } \\
& \text { 'our party that have come is approved by niniakmamak' }
\end{aligned}
$$

$$
\begin{aligned}
& \text { sarato karik jo kirabaik } \\
& \text { serta karib dan kerabat } \\
& \text { 'as well as all relatives' }
\end{aligned}
$$

The expressions (14) and (15) are fragments of TPMM in Solok city. The guests or entourage of 'bride's family' want to pick candidates of 'bridegroom' to the 'bride's family's house to be married and juxtaposed in the house of the candidates of 'bride's family's house. In Minangkabau traditional ceremonies, every step and decision that will be taken by the interests of niniak mamak / penghulu adat 'the customary leader in his people' should discuss with their relatives and leaders. This can be seen in the speech (14) pihak dek kami nan datang lah salapeh niniak jo mamak sarato karik jo kirabaik 'our party that has arrived has already been approved by the customary leaders and relatives'. The speech contains the values of unity. It is because the essential elements of mamak and intimates of relatives support each other and complement each other against the planned activities that have been agreed upon by both parties previously. The schedule and forms of activities in advance have been agreed by both parties. This is reflected in the following TPMM.

(16) nak manyampaikan niaik nak AKT.sampai -SUFF. niat 'want to convey intentions'

(17) kato dahulu batapeki, kato kudian indak bacari kata dahulu PREF.tepat SUFF. kata kemudian NEG. PREF.cari 'the previous word is kept up, the later one is not searched'

(18) pihakdek kami nan datang, nak mandapeki katonan dahulu pihak PREP. 1JMK nan datang AKT.dapat-SUFF. kata yang dahulu 'our party who comes wants to keep previous promise'

In the phrase (16), nak manyampaikan niaik 'want to convey intentions'; (17) kato dahulu batapeki, kato kudian indak bacari 'the previous word is kept up, the lateris not searched'; and (18) pihakd ek kami nan datang, nak mandapeki kato nan dahulu 'our party who comes wants to keep previous promise' reflects the value of unity and unification. The core problems discussed in the expression (16-18) are in expressions (17) and (18). The phrase kato dahulu in kato dahulu batapeki 'the previous word is kept up' (17) has the same meaning with the agreement which should be kept up. Meanwhile, kato kudian in kato indak bacari 'the later one is not searched' (17) has the meaning that something is not in the agreement. This implies that both parties must agree together and support the event in accordance with a predetermined schedule.

To achieve hope, someone does various ways. This is reflected in the following TPMM.

(19) manjuluak naknyo lareh, mamanggang naknyo masak AKT.juluk agar jatuh, AKT.panggang agar masak 'stick to fall, bake to cook' 
(20) manjapuik nak tabao nak manjapuik rang sumando

AKT.jemput agar PREF.bawa, untukAKT.jemput orang semenda 'pick up to get carried away, to pick up the fines'

(21) manantu kami nan banamo Alfajri menantu 1JMK yang PREF.nama Alfajri

'our son-in-law named Alfajri'

The words manjuluak 'dub', mamanggang 'roast', and manjapuik 'pick up' on expressions (19 and 20) are figurative expressions in the form of attempts to reach a hope.

The phrase manjuluak 'sticking' is used by people to dub fruits so that they fall down from the tree. The word mamanggang 'grilling' means activities related to cook food. Usually baked foods will cook or ripen so they can be eaten, such as roasted corn, grilled fish, grilled meat (satay), grilled chicken, and others. The expressions are figure of speech expressed by bride's niniak mamak/ datuk 'the leader of customary'. This is confirmed by the expression (20) manjapuik nak tabao, manjapuik sumando kami 'picking up to be carried away our brother-in-law, and (21) 'our son-inlaw' named Alfajri'. In every effort, a person has hope that his business will succeed. It is the same as the efforts of the bride's family to carry the bridegroom and his accompaniment to bride's family house. This is reflected in the following expression.

(22) kok japuik, japuik tabao basarato pangiriangnyo dek Malin

kalau jemput, jemput PREF. bawaPREF.sertaPREF.iring-KL PREF. Malin

'if you pick up, pick up and get along with accompaniment, Malin'

\section{(23) kok kandak babari, kok pintak iyo bapalakuan}

kok kehendak PREF.beri, kok pintak FAT. PREF.lakuSUFF

'how come the will is enforced, how come the request is treated'

Expressions (22 and 23) are disclosed by the candidate of bride's family who will pick up the candidate of bridegroom and his family. It contains values of unity and unification. This is marked by the phrase basarato pangiriangnyo 'and his accompaniment'. In the pasambahan manjapuik marapulai ceremony, what was picked up was not only the candidate of bridegroom, but also niniak mamak, datuak, 'traditional leaders', and relatives of the candidate of bridegroom. This reflects the values of unity and unification.

In addition, expressions (22 and 23) indicate an expectation. The expression is conveyed by the candidate of bride's family with the hope that he could bring the candidate of bridegroom and his family to the house of bride's house to be juxtaposed and married in the bride's family house. This is reflected in the expression (22). The hope of being able to pick up the candidate of bridegroom is reaffirmed by the expression (23) 'how come the will is enforced, how come the request is treated'.

\subsection{Willing to sacrifice}

Willing to sacrifice is someone's sincerity to help others in the form of material and non-material. Everything that is done for others is a noble act and is recommended both in religion and in Minangkabau customs. In the TPMM in Solok city, it is reflected a willingness to sacrifice. In the process of manjapuik marapulai 'picking up the candidate of bridegroom' involving many elements such as niniak mamak / traditional leaders, bundo kanduang, as well as all close friends, both the candidate of bride and bridegroom (those who pick up and those who are picked up). This willingness to sacrifice is always owned by the communal community. In communal societies, it is always upholding togetherness and selflessness. Likewise, Minangkabau sense to help to each other is still strong. The willingness to sacrifice is reflected in the following TPMM.

(24a) salangkah turun dari ranjang, dari tangah rumah di kampuang tu selangkah turun PREP. ranjang PREP. PREP. rumah PREP. kampung sana 'one step down from the bed, from the house in that village'

(24b) barieh tabantang kami turuik, labuah nan goloang kami tampuah rintanganterbentang $1 \mathrm{JMK}$ turut, labuh yang golong $1 \mathrm{JMK}$ tempuh 'we stretched outthe obstacles, what we used to do'

(24c) datang ka jorong kampuang datuak datang ke jorong kampung datuk 'come to your village, datuk' 
The expression (24a-24c) as a whole reflects the value of being willing to sacrifice. The expression is conveyed by the candidate of the bride's family at the candidate bridegroom's house. The phrase recounts the journey of the candidate of the bride's family arrived at candidate of bridegroom's house which is full of twists and sacrifices to achieve a common goal, namely to pick up the bridegroom. The community is willing to put aside their personal needs to meet common needs. In a communal society, besides being willing to sacrifice in both material and non-material forms as described above, a sense of solidarity is also embedded. This sense of solidarity arises because of the same compliance with the system of values and norms that apply in a community. This is in line with Hendropuspito (1989) and Koentjaraningrat (1990) which mention that to help each other, it is based on moral feelings, and a solid sense of brotherhood.

\section{Conclusion}

Based on the research that has been done on the text of pasambahan manjapuik marapulai in Solok city, it is found that the process of the text of traditional marriage obtain the values of mutual cooperation as local wisdom. Pasambahan is a sacred ceremony, because every traditional ceremony in Minangkabau is carried out in a customary manner, the pasambahan must be present. The form of local wisdom is full of the philosophical meaning of the value of mutual cooperation in the process of manjapuik marapulai 'picking up the bridegroom' in a customary manner. The values of mutual cooperation are:

(1) Togetherness. Participants in the process of manjapuik marapulai traditionally respect each other's shared values that prioritize the common interest of personal interests;

(2) Mutual consensus. In the Minangkabau indigenous people, before deciding to do a work carried out in a traditional ceremony together, it should be discussed with their people or with other parties first;

(3) Unity and unification. In Minangkabau traditional ceremonies, every step and decision that will be taken by niniak mamak 'customary leader' must be discussed with relatives and leaders of their people; and

(4) Willing to sacrifice. Participants in the process of picking up the bridegroom process involved many elements such as niniak mamak 'Minangkabau traditional leaders', element of bundo kanduang, as well as all relatives, both bride and bridegroom's family (those who picked up, and to be picked up) willing to sacrifice in thought, energy, and material for the success of the event.

\section{Bibliography}

Amir, M.S. 1999. Adat Minangkabau: Pola dan Tujuan Hidup Orang Minang. Jakarta: PT Mutiara Sumber Widya. Bakar, Jamil, dkk. 1976. "Sastra Lisan Minangkabau: Tradisi Pasambahan Helat Perkawinan" (Laporan Penelitian). Padang: Departemen Pendidikan dan Kebudayaan.

Collette. 1987. Sistem Gotong Royong Dalam Masyarakat. Jakarta: Gramedia Pustaka

Djajasudarma, T. Fatimah. 1993. Metode Linguistik: Ancangan Metode Penelitian dan Kajian. Bandung: Eresco.

Djamaris, Edwar. 2001. Pengantar Sastra Rakyat Minangkabau. Jakarta: Yayasan Obar Indonesia.

Elfiando, Zulfian. 2000. Pasambahan Mananti Marapulai di Kotamadya Solok. Tesis. Denpasar: Universitas Udayana. Firman. 2015. Perubahan Sosial dalam Pergeseran Sistem Kegotongroyongan di Daerah Minangkabau.

Hakimy, Idrus 1980. Pokok-pokok Pengetahuan Adat Alam Minangkabau. Bandung: PT Remaja Rosdakarya.

Hakimy, Idrus 1984. Pegangan Penghulu, BundoKanduang, dan PidatoAlua Pasambahan Adat di Minangkabau. Bandung: CV Remadja Karya.

Halliday, M.A.K. and Hasan R. 1978. Language as Social Semiotic: The Social Interpretation of Language and Meaning. London: The Pitman Press.

Herlina, 2018. Nilai Kearifan Lokal dalam Novel Negeri Sapati, karyaLaode. M. Insan sebagai Pendukung Pelaksanaan Pendidikan Karakter, dalam Jurnal Pendidikan Bahasa Vol. 3, No.2.

Iriani, 2018. Solidaritas Relanggae pada Upacara Perkawinan Adat Padoe. Sulawesi: BPNB.

Kartodirdjo,Sartono. 1994. Kebudayaan Pembangunan DalamPerspektif Sejarah. Yogyakarta: Gadjah Mada University Press.

Levinson, Stephen C. 1983. Pragmatics. Cambridge: Cambridge University Press.

Moleong, Lexy J. 2005. Metodologi Penelitian Kualitatif. Bandung: CV RemadjaKarya.

Navis, A.A. 1984. Alam Terkembang Jadi Guru: Adat dan Kebudayaan Minangkabau. Jakarta: Grafiti Pers.

Nurlatifah.2017. Gotong Royong sebagai Wujud Integrasi Lokal dalam Perkawinan Adat Banjar sebagai Sumber Pembelajaran IPS di Desa Hakim Makmur Kecamatan Sungai Pinang.https: //ppjp.ulm.ac.id/ journal/ index.php/ JS/article/.../ 3354/2910

Oktara, M. HidayatDwi. 2014. Gotong-Royong sebagai Nilai Kearifan Lokal dalamTradisi Barong Ider Bumi di Desa Kemiren, Kecamatan Glagah, Kabupaten Banyuwangi. Skripsi, Jurusan Hukum dan Kewarganegaraan, Fakultas Ilmu Sosial, Universitas Negeri Malang. 
Pasya, Gurniwan Kamil. 2015. Gotong Royong Dalam KehidupanMasyarakat. Artikel Ilmiah. Bandung: Universitas Pendidikan Indonesia.

Pranadji.2009. Penguatan Kelembagaan Gotong Royong Dalam Perspektif Sosio Budaya Bangsa: Suatu Upaya Revitalisasi Adat Istiadat Dalam Penyelenggaraan Pemerintahan. Jurnal FORUM PENELITIAN AGRO EKONOMI. Volume 27 no.1, Juli 2009:61-72. Bogor: Pusat Analisi Sosial Ekonomi dan Kebijakan Pertanian.

Rosa, Silvia. 2013. "Teks Pidato Pasambahan Batagak Gala di Minangkabau dalam PerspektifSemiologi Roland Barthes". Padang: Universitas Andalas.

Sibarani, Robert. 2014. Kearifan Lokal: Hakikat, Peran, dan MetodeTradisi Lisan. Jakarta: Diterbitkan oleh Asosiasi Tradisi Lisan (ATL)

Sudaryanto 1993. Metode dan Aneka Teknik Analisis Bahasa: Pengantar Penelitian Wahana Kebudayaan secara Linguistis. Yokyakarta: Duta Wacana University Press.

Udin, Syamsuddin, dkk.1984. "Sastra Lisan Minangkabau dalam Tradisi Pasambahan Batagak Panghulu" (Laporan Penelitian Bahasa dan Sastra Indonesia dan Daerah Sumatera Barat) Padang: Pusat Pembinaan dan Pengembangan Bahasa, Departemen Pendidikan dan Kebudayaan. 